\title{
Effectiveness of Organic Acid Treatments for Inhibition and Removal of $E$. coli Biofilms
}

\section{E. coli Biyofilmlerinin Önlenmesi ve Ortadan Kaldırılmasında Organik Asit Uygulamalarının Etkileri}

\author{
Research Article \\ Meltem Yeşilçimen Akbaş \\ Department of Molecular Biology and Genetics, Gebze Technical University, Gebze, Kocaeli, Turkey.
}

\section{A B STRACT}

\begin{abstract}
This study was carried out to evaluate the efficacies of organic acid (citric, malic and gallic acids) treatments at $1 \%$ and $2 \%$ concentrations for prevention and removal of $E$. coli biofilms. Antibiofilm effects of organic acids were compared with chlorine $(100 \mathrm{ppm}$ and $200 \mathrm{ppm})$ on both microtitration plate and stainless steel coupons for 5, 10 and 20 min. Results indicated that citric acid treatments when compared to the chlorine treatments were effective for inhibition and removal of $E$. coli biofilms. On the other hand, gallic acid treatments were found to be more effective than malic acid treatments. On stainless steel surfaces, the inhibition and removal of biofilms were observed to be higher than those found on microtitration plates. Moreover, the inhibition and removal ratios were calculated to be higher with increasing concentrations of sanitizers, on 24-h biofilm, on stainless steel coupons and with 20 min treatments. The results of this study indicates chlorine treatments could be replaced by organic acid treatments for inhibition and removal of biofilm formations of $E$. coli strains on different food contact surfaces. In addition, organic acid treatments are safe-to-use potential alternatives in industrial applications to chlorine treatments which is toxic to health and environment.
\end{abstract}

\section{Key Words}

Biofilm inhibition, biofilm removal, E. coli, food contact surfaces, organic acids.

\section{ÖZET}

$\mathrm{B}$ u çalışmada, E. coli biyofilmlerinin önlenmesi ve ortadan kaldırılmasında \%1 ve \%2 derişimlerdeki organik asit (sitrik, malik ve gallik) uygulamalarının etkileri araştırılmıştır. Organik asitlerin antibiyofilm etkileri klor uygulamaları (100 ppm ve 200 ppm) ile 5, 10 ve 20 dakika süresince mikrotitrasyon plaklarında ve paslanmaz çelik kuponlarda karşılaştırılmıştır. Sonuçlar biyofilmlerin önlenme ve ortadan kaldırılmasında, klor uygulamaları ile karşılaştırıldı̆̆ında, sitrik asit uygulamalarının etkili olduğunu göstermiştir. Gallik asit uygulamaları ise malik asit uygulamalarından daha etkili bulunmuştur. Çelik yüzeylerde, biyofilm önlenmesi ve ortadan kaldırılması oranları mikrotitrasyon plaklarından daha yüksek bulunmuştur. Ayrıca, biyofilm önlenme ve ortadan kaldırılma oranları, sanitizerların artan derişimlerinde, 24 saatlik biyofilm tabakası üzerinde, çelik yüzeylerde ve 20 dakikalık uygulamalarla daha yüksek değerlerde bulunmuştur. Çalışmanın sonuçları, farklı gıda ile temas eden yüzeylerde, $E$. coli biyofilmlerinin önlenmesi ve ortadan kaldırılmasında, organik asit uygulamalarının klor uygulamalarının yerini alabileceğini göstermektedir. Ayrıca organik asitler, endüstriyel uygulamalarda kullanılan sağlığa ve çevreye toksik etkili olan klorun kullanımının güvenli potansiyel alternatifleri olabilir.

\section{Anahtar Kelimeler}

Biyofilm önlenmesi, biyofilm ortadan kaldırılması, E. coli, gıda ile temas eden yüzeyler, organik asitler.

\footnotetext{
Article History: Received: Jan 7, 2016; Revised: Feb 2, 2016; Accepted: Mar 16, 2016; Available Online: Apr 01, 2016. DOI: $10.15671 /$ HJBC.20164417565
}

Correspondence to: M.Y. Akbaş, Department of Molecular Biology and Genetics, Gebze Technical University, Gebze-Kocaeli, Turkey. 


\section{INTRODUCTION}

The he control of food borne pathogens has received a great deal of attention in recent years. The reason for this is due to the fact that these organisms can form biofilms on different surfaces [1]. It is highly likely that they can cause significant health problems when they contaminate lifeline systems such as drinking water transmission lines and food processing environments [2].

In food industry, microbial cell transfer from biofilms to foods is a potential source of hazard for food safety and quality. In addition, food spoilage due to biofilms results in huge economic losses and has potential health risks [3]. Biofilm formation facilitates survival under stressed conditions such as ultraviolet radiation, physicochemical stresses and insufficient supply of nutritive resources. Previous studies indicate that bacteria in biofilms can be up to 10-1000 times more resistant to the effects of antimicrobial agents than planktonic bacterial cells $[4,5]$. The chemical control of biofilms is important due to the increased resistance of biofilm embedded bacteria to disinfectants. Resistance against various disinfectants gets higher as the biofilm matures, especially, after about 24 hours [6]. Therefore, one of the best ways of controlling biofilms is to prevent their development.

Food contact surfaces has great potential for allowing biofilm development. The adhesion surface properties and the bacterial cells are key factors that affect the biofilm formation. Since the food contact surfaces such as stainless steel, glass, rubber, and polypropylene surfaces can be contaminated easily by pathogenic microorganisms, the selection of surface material has substantial impact in designing food contact surfaces. Among these, stainless steel surfaces are preferred for food equipment and are specified in many industries [7].

Pathogenic bacteria can initiate cellular growth to make biofilms when adhered to the surface under certain conditions [8]. Bacillus, Salmonella, Listeria, Staphylococcus and Escherichia bacteria when adhered in food processing environment may cause food spoilage or transmission of food-borne diseases $[3,9]$.
The presence of $E$. coli in foods such as milk, meat and vegetables is an indicator of fecal contamination causing outbreaks of many diseases [10]. A recent study has also shown that $E$. coli had the ability to attach strongly to leafy structures [11].

Food contact surfaces are commonly disinfected with different compounds such as peroxides, chloramines or hypochlorites [12]. These compounds should be effective enough as to inactivate the pathogens while maintaining organoleptic properties of the product [11]. Moreover, corrosion and toxicity limit the use of these commercial compounds [13].

Among the commercial sanitizers, chlorine in its various forms, is the most commonly used sanitizer in food industry. Liquid chlorine, hypochlorites, inorganic or organic chloramines are widely used chlorine compounds. Chlorine is a relatively cheap disinfectant and known to be active at low temperature. One of the major drawbacks of chlorine is that it causes corrosion on metal surfaces as well as skin irritation and mucous membrane damage. Moreover, the use of chlorine as a drinking water disinfectant causes the formation of potentially carcinogenic trihalomethanes (THMs) under certain conditions. This fact indicated the need of developing new and safe biofilm control strategies. The interest in antimicrobials derived from natural sources has increased in recent years $[14,15]$. One approach may be the use of organic acids (citric, malic, gallic acids etc.) as antimicrobial agents. Organic acids are widely distributed in plants and animals. They are considered to be safe in terms of human and animal health with no toxic residues. Organic acids can be as effective as chemical disinfectants [1618]. Eswaranandam et al. [16] found that organic acids such as malic, citric, lactic, and tartaric acid had antibacterial activity at specific $\mathrm{pH}$ conditions. Over et al. [18] treated Salmonella Typhimurium inoculated boneless chicken breast meat with 150 mM citric acid, malic acid and tartaric acid. The researchers found that S. Typhimurium numbers stored at $4^{\circ} \mathrm{C}$ were near undetectable levels by the end of day 9. 
Citric acid is a hydroxy tricarboxylic acid produced naturally by various plants. It is approved and classified as GRAS (21CFR184.1033) for use in the manufacture of fresh and processed poultry and meats [19]. Citric acid inhibits bacterial cells via metal chelation. In a previous study, dipping of fresh-cut iceberg lettuce in citric acid solution $(0.5 \%, w / v)$ was found to be effective as chlorine solution $(100 \mathrm{ppm})$ for inactivating pathogenic microorganisms [17].

Malic acid is a dicarboxylic acid found in many foods. The studies determined that it can be used to treat food borne pathogens $[20,21]$. It was reported that malic acid could inhibit the growth of Listeria monocytogenes, Salmonella gaminara, and Escherichia coli 0157: H7 [22]. Malic acid affects food borne microbial pathogens by lowering the $\mathrm{pH}$ value [23] by causing severe damage to the cytoplasm of bacteria [16]. Singla et al. [24] found that malic acid was effective in food industry for complete inhibiton of S. Typhimurium biofilm in carrot and other food contact surfaces.

Gallic acid is one of the abundant polyphenol and widely distributed among plants [25]. It has been shown to possess strong antimicrobial activity [26]. Borges et al. [27] investigated the activity of gallic acid at $1000 \mu \mathrm{g} / \mathrm{ml}$ on the prevention and control of biofilms formed by Escherichia coli, Pseudomonas aeruginosa, Staphylococcus aureus and L. monocytogenes. The researchers found that gallic acid has potential to prevent and control these pathogens by promoting reductions in biofilm activity higher than $70 \%$ of all tested microorganisms.

This study investigates the activity of organic acids (citric, malic and gallic acids) at $1 \%$ and $2 \%$ concentrations in order to prevent and remove (from 5 to 20 min treatment) 24-hour, 48-hour and 72 -hour $E$. coli biofilms on both microtitration plate and stainless steel coupons. The surface materials (polystyrene microtitration plate and stainless steel), concentrations, treatment times and the biofilm age on the antibiofilm effects of these organic acid treatments are compared with a commercial, chlorine (100 ppm and 200 ppm) treatments on both surfaces.

\section{MATERIALS AND METHODS}

\section{Microorganism and Culture Conditions}

In this work, E. coli ATCC 25922 was used as a model microorganism. Stock culture of this strain was stored at $-20^{\circ} \mathrm{C}$ in TSB supplemented with $20 \%$ glycerol. Working culture was maintained on nutrient agar containing plates at $4^{\circ} \mathrm{C}$.

\section{Preparation of Solutions}

All sanitizing solutions were prepared daily using sterilized distilled water. For the purpose of obtaining a solution with concentrations of $100 \mathrm{mg} / \mathrm{l}(\mathrm{ppm})$ and $200 \mathrm{mg} / \mathrm{l}(\mathrm{ppm})$ free chlorine, chlorinated water was prepared by adding sodium hypochlorite $(\mathrm{NaOCl})$ solution to pre-sterilized distilled water containing 13\% active chlorine (Merck, Darmstadt, Germany). Chlorine concentrations within the solutions were measured by using a commercial chlorine test kit (Merck, Darmstadt, Germany). Citric, malic and gallic acids were provided from Merck (Darmstadt, Germany). They were used to prepare solutions containing citric acid ( $1 \%$ and $2 \%, w / v)$, gallic acid $(1 \%$ and $2 \%, w / v)$, or malic acid ( $1 \%$ and $2 \%, w / v)$. The prepared fresh solutions were used within 30 min.

\section{Biofilm Forming Ability on 96-well Polystrene Microtitration Plate}

The modified microtitration plate test proposed by Stepanovic et al. [28] was performed to assess the biofilm formation ability of $E$. coli on microtitration plate. E. coli strain was grown overnight at $37^{\circ} \mathrm{C}$ in tryptic soy broth (TSB, Becton, Dickinson, and Company, France) supplemented with $2 \%(\mathrm{w} / \mathrm{v})$ D-glucose (TSBGIC). Following incubation at $37^{\circ} \mathrm{C}$ for 24 hour, culture supernatant was diluted at a rate of 1:200 in fresh TSBGIc. An aliquot bacterial suspension (200 $\mu \mathrm{l}$; about $10^{5} \mathrm{cfu} / \mathrm{ml}$, final cell density) was transferred into 96 well polystyrene microtitration plate (Nunc, Roskilde, Denmark). The medium without the bacterial suspension was used as the negative control during the test. The plates were incubated at $37^{\circ} \mathrm{C}$ for three different time periods (24-, 48- or 72-hours). Then, culture supernatants from each well were first gently removed by pipetting and washed three times with distilled water. The attached cells were stained with $0.5 \%(\mathrm{w} / \mathrm{v})$ crystal violet $(150 \mu \mathrm{l})$ solution and the bound crystal violet was resolubilized with 33\% 
(v/v) glacial acetic acid $(150 \mu \mathrm{L})$ for $10 \mathrm{~min}$. The OD value of each well at $570 \mathrm{~nm}$ was measured using microplate reader (BMG Labtech Fluostar Omega ELISA, Germany). The microtitration plate biofilm assay was performed in triplicate. Biofilm formation was interpreted as positive for cases where OD570 $>0.1$ or negative for cases where OD570 $<0.1$ These $O D$ values were considered for an index of bacteria adhering to surface and forming biofilms.

\section{Biofilm Forming Ability on Stainless Steel}

Stainless steel coupons $(20 \times 40 \times 1 \mathrm{~mm})$ were rinsed with distilled water and autoclaved at $121^{\circ} \mathrm{C}$ for 30 min. After autoclaving, the sterile steel coupons were placed in a $100 \mathrm{ml}$ sterile glass container with $50 \mathrm{ml}$ fresh TSBG. Then, the medium was inoculated with overnight culture of $E$. coli strain The final cell density in TSBG was about $10^{5} \mathrm{cfu} /$ $\mathrm{ml}$. The containers were incubated in an incubator at $37^{\circ} \mathrm{C}$ for 24,48 or 72 hours. The steel coupons were transferred to a new $100 \mathrm{ml}$ sterile container with $50 \mathrm{ml}$ of $0.5 \%(\mathrm{w} / \mathrm{v})$ crystal violet solution. The crystal violet bound to the biofilm was solubilized with $50 \mathrm{ml}$ of $33 \%(\mathrm{v} / \mathrm{v})$ glacial acetic acid for 10 min and the absorbance was determined at 570 $\mathrm{nm}$ by using the microplate reader (BMG Labtech Fluostar Omega ELISA, Germany). $150 \mu$ of TSBG was dispensed into each well for negative controls. The biofilm assay was again performed in triplicate as in the case of microtitration plate assay.

All experiments on microtitration plates and stainless steel coupons were repeated three times on different days and with all solutions freshly prepared.

\section{Inhibition of Biofilm Formation}

Organic acids (citric, gallic and malic acids) at concentrations of $1 \%$ and $2 \%(w / v)$ were tested for comparison with chlorine solution $(100 \mathrm{ppm}$ and $200 \mathrm{ppm}$ ) ffor their potential to prevent biofilm formation of $E$. coli strain after 24-hour, 48-hour or 72-hour.

\section{Inhibition of Biofilm Formation on 96-Well Polystrene Microtitration Plate}

For this purpose, the wells of microtitration plates were loaded with citric, malic or gallic acids (1\% or $2 \%, w / v)$ or chlorine (100 ppm or $200 \mathrm{ppm}$ ) solutions. After each treatment, each well was first decanted by pipetting and then, the wells were air dried at room temperature for $30 \mathrm{~min}$. $E$. coli strain was grown overnight at $37^{\circ} \mathrm{C}$ on tryptic soy broth (TSB, Becton, Dickinson, and Company, France) supplemented with $2 \%(\mathrm{w} / \mathrm{w}) \mathrm{D}$-glucose (TSBGIC). Following the incubation at $37^{\circ} \mathrm{C}$ for $24^{-}$ hour, the culture supernatant of $E$. coli strain was diluted at a rate of 1:200 in fresh TSBGIc. Aliquots of bacterial suspension $\left(200 \mu \mathrm{L} ; 5 \times 10^{5} \mathrm{cfu} / \mathrm{ml}\right.$, final concentration) were transferred into citric acid, malic or gallic acid ( $1 \%$ or $2 \% \mathrm{w} / \mathrm{v}$ ) or chlorine solution (100 ppm or $200 \mathrm{ppm}$ ) treated polystyrene microtitration plate (Nunc, Roskilde, Denmark) for incubation at $37^{\circ} \mathrm{C}$ for 24 -hour, 48 -hour or 72 -hour. For negative controls, $150 \mu$ l of TSBG were dispensed into each well. Biofilm formation experiments on microtitration plates were carried out similar to the ones in previous sections.

\section{Inhibition of Biofilm Formation on Stainless Steel Coupons}

Sterile stainless steel coupons were treated with $50 \mathrm{~mL}$ organic acids $(1 \%$ or $2 \%, \mathrm{w} / \mathrm{v}$, citric, malic or gallic acid) or chlorine (100 ppm or 200 ppm) solution in $100 \mathrm{ml}$ sterile glass containers. After each treatment, the coupons were air dried at room temperature for $30 \mathrm{~min}$. Sterile steel coupons were placed in a new $100 \mathrm{ml}$ sterile glass container with fresh $50 \mathrm{ml}$ TSBG. The medium was inoculated with overnight culture of $E$. coli strain. The final cell density was about $10^{5} \mathrm{cfu} / \mathrm{ml}$. The medium without the bacterial suspension was used as the negative control. The containers were incubated in an incubator at $37^{\circ} \mathrm{C}$ for 24 -hour, 48 -hour or 72 -hour. Biofilm formation experiments on stainless steel coupons were again carried out similar to the ones in in previous sections.

\section{Removal of Biofilm Formation}

For this purpose, biofilm formation assays were performed as described in the previous sections on both microtitration plates and stainless steel coupons. Organic acid (citric, malic and gallic acids) at $1 \%$ or $2 \%(\mathrm{w} / \mathrm{v})$ concentrations were tested and compared with chlorine solution (100 ppm or 200 ppm) for 5, 10 and 20 min to explore their potential biofilm removal activities on 24-hour, 48-hour and 72 -hour aged biofilm formations of $E$. coli. The experiments were performed on both microtitration 
plates and stainless steel coupons.

The percentages of biofilm prevention and removal were calculated as [29]:

Prevention or removal of biofilm (\%) =

$[(C-B)-(T-B)] /(C-B) \times 100$

where $B$ was the average absorbance per well with no biofilm (negative control), $\mathrm{C}$ was the average absorbance per well for non-treated wells (positive control) and T was the average absorbance per well for the sanitizer treated wells.

\section{Statistical Analysis}

Three independent trials were conducted. Analysis of variance (anova) was performed with SPSS (SPSS Inc.,version 11.5, Chicago, Illinois, USA) followed by post hoc Tukey's test with a level of significance at $P<0.05$.

\section{RESULTS}

The experiments yielded in enhanced biofilm formation on microtitration plates as compared to stainless steel coupons. The biofilm formation was determined at 24-hour (early, O.D. values 0.3) of incubation and enhanced at 48-hour (mature, OD values 0.5 ) and 72-hour (more mature, OD values 0.9) in microtitration plates. On the stainless steel coupons, lower OD values were determined for early (OD values 0.2), mature (OD values 0.3 ) and more mature (OD 0.6) biofilm formations.

\section{Chlorine treatments on microtitration plates}

Inhibition of biofilm formations was in the range of $74-80 \%(p<0.05)$ after 24-, 48- and 72-hour when 100 ppm chlorine was used before the biofilm formation. On the other hand, the inhibition ratios increased significantly up to $83-87 \%$ ( $p<0.05$ ) by using 200 ppm chlorine before the biofilm formation (Figure 1A).

Removal of biofilm formation was about between $42-50 \%$ ( $p<0.05)$ by using 100 ppm for 5 to 20 min while up to $57-69 \%$ ( $<<0.05$ ) removal ratios were determined when 200 ppm chlorine was used for the same treatment times on 24-, 48- and 72-hour pre-formed biofilm formations (Figure 2A).

\section{Organic Acid Treatments on Microtitration Plates Citric Acid Treatments}

Biofilm formation was prevented about $80-85 \%$ ( $p<$ 0.05 ) when $1 \%$ citric acid was used before the biofilm formation. When the citric acid concentration was increased from $1 \%$ to $2 \%$, substantially increased inhibition rates were detected up to $84-86 \%$ ( $p$ > 0.05) (Figure 1B).

Removal of biofilms were up to $47-55 \%$ ( $p<$ 0.05 ) by using $1 \%$ citric acid in $24-, 48$ - and 72 -hour old E. coli biofilms. Increasing the concentration of citric acid from $1 \%$ to $2 \%$ and the treatment time from $5 \mathrm{~min}$ to $20 \mathrm{~min}$ resulted in significant decrease of biofilm formation up to $55-64 \%$ ( $p<$ 0.05) (Figure 2B).

\section{Malic Acid Treatments}

Biofilm formation was inhibited about $52-65 \%$ ( $p<$ 0.05 ) with $1 \%$ malic acid treatment. However, the inhibition ratio of biofilm formation was increased significantly 55-68\% ( $p>0.05$ ) after $24-, 48-$ and 72 -hour when the concentration of malic acid was increased from $1 \%$ to $2 \%$ (Figure $1 C$ ).

Biofilm formation was removed up to $39-52 \%$ $(p<0.05)$ when $1 \%$ malic acid was used for 5 to 20 min for 24-, 48- and 72-hour aged biofilms. When the concentration of malic acid and the exposure time were increased, the removal ratios of biofilm formations substantially increased up to 42 to $59 \%$ $(p<0.05)$ after 5 to 20 min treatments on 24-, 48and 72 -hour pre-formed biofilms (Figure $2 \mathrm{C}$ ).

\section{Gallic Acid Treatments}

The inhibition rates of biofilm formations were between $61-70 \%(p<0.05)$ after $24-, 48-$ and $72-$ hour when $1 \%$ gallic acid treatments were used before the biofilm formation while the ratios significantly increased up to $67-76 \%(p<0.05)$ for 5 to $20 \mathrm{~min}$ (Figure 1D).

Biofilm formation was reduced only about $42-$ $62 \%$ ( $p<0.05$ ) after using $1 \%$ gallic acid for 5 to 20 min for 24-, 48- and 72-hour old biofilm formations. When the gallic acid concentration was increased from $1 \%$ to $2 \%$, the reduction ratios of biofilm formation increased significantly by $52-70 \%$ ( $p$ 0.05 ) by using the same treatment times on 24-,48and 72-hour aged biofilms (Figure 2D). 

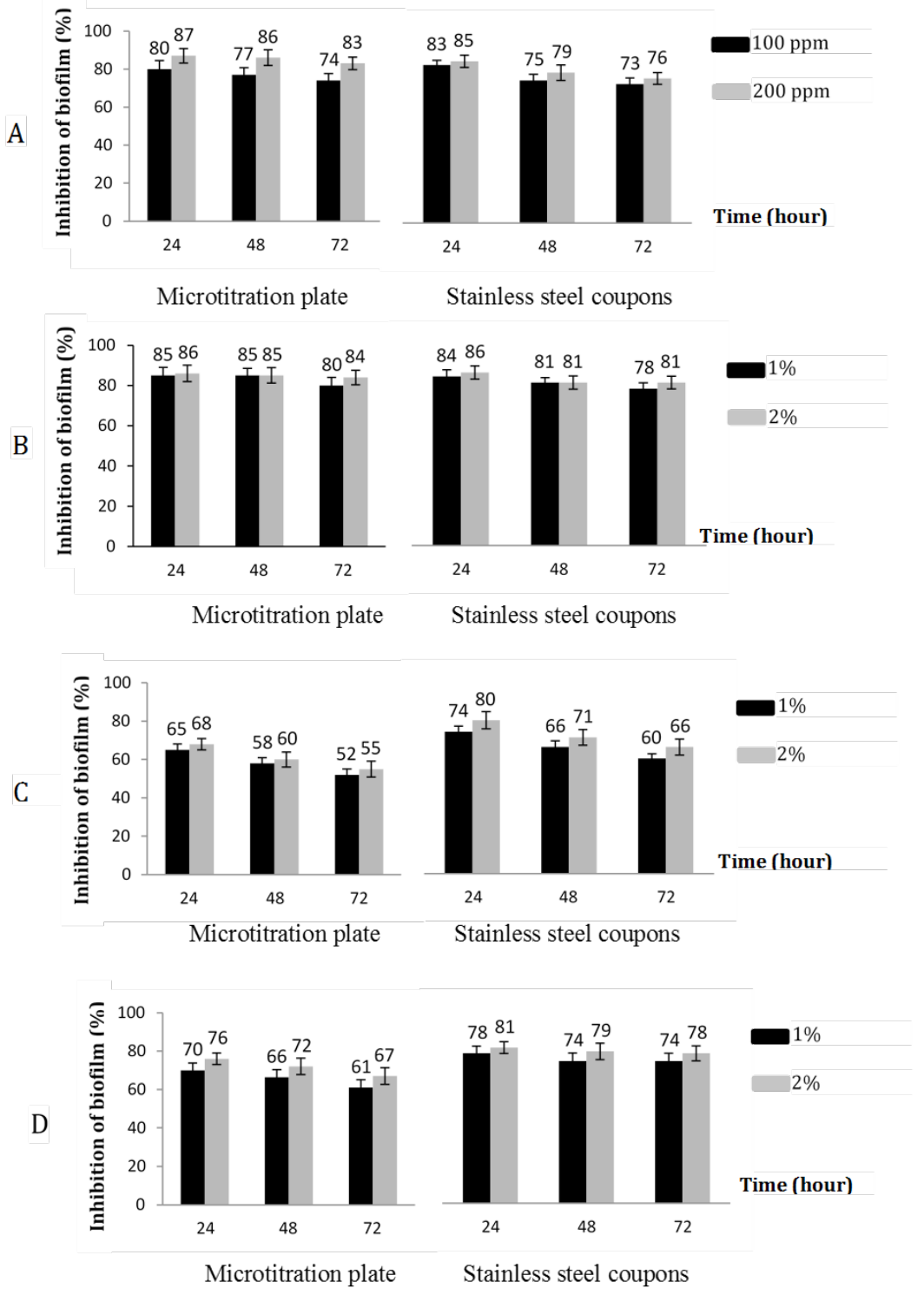

Figure 1. Effects of chlorine (A) and organic acid treatments (B: citric acid; C: malic acid; and D: gallic acid) for inhibition of 24- hour; 48- hour; and 72- hour E. coli biofilm formations on microtitration plate and stainless steel coupons. Mean values \pm standard deviation for three independent experiments performed in duplicate.

Chlorine Treatments on Stainless Steel Coupons On stainless steel coupons, biofilm formations were inhibited by up to $73-83 \%(p<0.05)$ with 100 ppm chlorine treatment after 24-, 48- and 72-hour. When the concentration was increased from $100 \mathrm{ppm}$ to $200 \mathrm{ppm}$, the inhibition rates remained at $76-85 \%$ $(p>0.05)$ (Figure 1A).

Removal of biofilm ratios was about $60-80 \%$ $(p<0.05)$ by using $100 \mathrm{ppm}$ chlorine while the reduction ratios increased to $68-87 \%(p<0.05)$ when the concentration and the treatment time were increased from $100 \mathrm{ppm}$ to $200 \mathrm{ppm}$ for 5 to 20 min on 24-, 48- and 72-hour old biofilm formations (Figure $3 \mathrm{~A}$ ).

\section{Organic Acid Treatments on Stainless Steel Coupons}

\section{Citric Acid Treatments}

Biofilm formations were inhibitied about $78-84 \%$ $(p<0.05)$ with $1 \%$ citric acid treatments while ratios remained about $81-86 \%(p>0.05)$ by using $2 \%$ citric acid treatments after 24-, 48- and 72-hour (Figure 1B). 

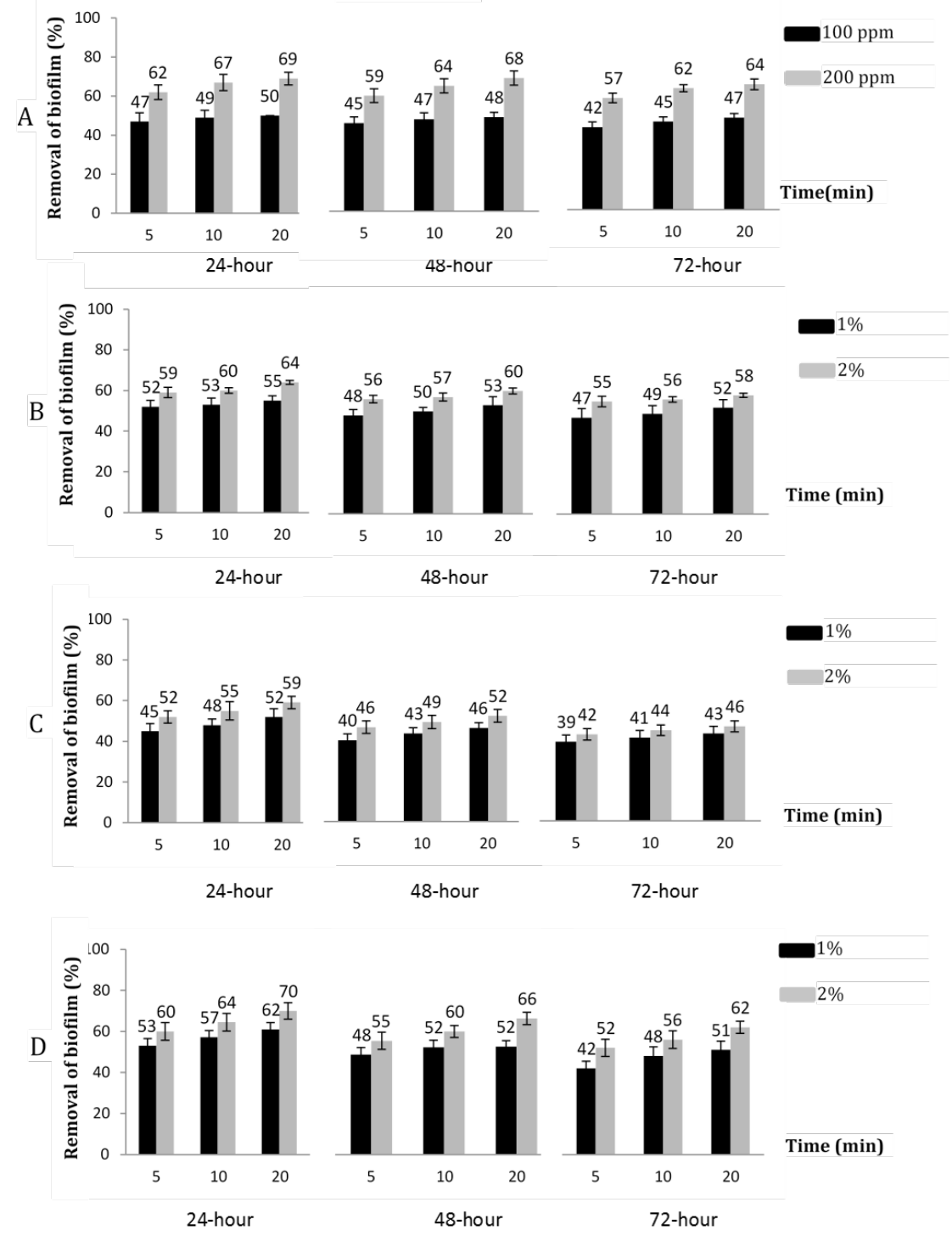

Figure 2. Effects of chlorine (A) and organic acid treatments (B: citric acid; C: malic acid; and D: gallic acid) for removal of 24-hour; 48-hour; and 72- hour $E$. coli biofilm formations on microtitration plate. Mean values \pm standard deviation for three independent experiments performed in duplicate.

Biofilm formations were reduced about $66-85 \%$ p 0.05 ) after using $1 \%$ citric acid for 5 to $20 \mathrm{~min}$ on 24 - 48 - and 72 -hour old biofilms. When the citric acid concentration was increased from $1 \%$ to $2 \%$, the reductions increased quite signficantly up to $71-$ $91 \%(p<0.05)$ for the same treatment times on the same aged biofilm formations (Figure 3B).

\section{Malic acid Treatments}

The ratios of prevention of biofilm formations were about $60-74 \%(p<0.05)$ by using $1 \%$ malic acid, whereas the rates substantially increased up to
$66-80 \%(p<0.05)$ when the concentration of malic acid was increased from $1 \%$ to $2 \%$ after $24-, 48$ - and 72-hour (Figure 1C).

Removal of biofilm formation ratios were between $47-68 \%(p<0.05)$ with $1 \%$ malic acid treatments for 5 to 20 min in 24-, 48- and 72-hour $E$. coli biofilm formations. The rates were significantly enhanced up to $57-76 \%(p<0.05)$ when $2 \%$ malic acid was used for 5 to 20 min for 24-, 48- and 72hour pre-formed biofilm formations (Figure 3C). 

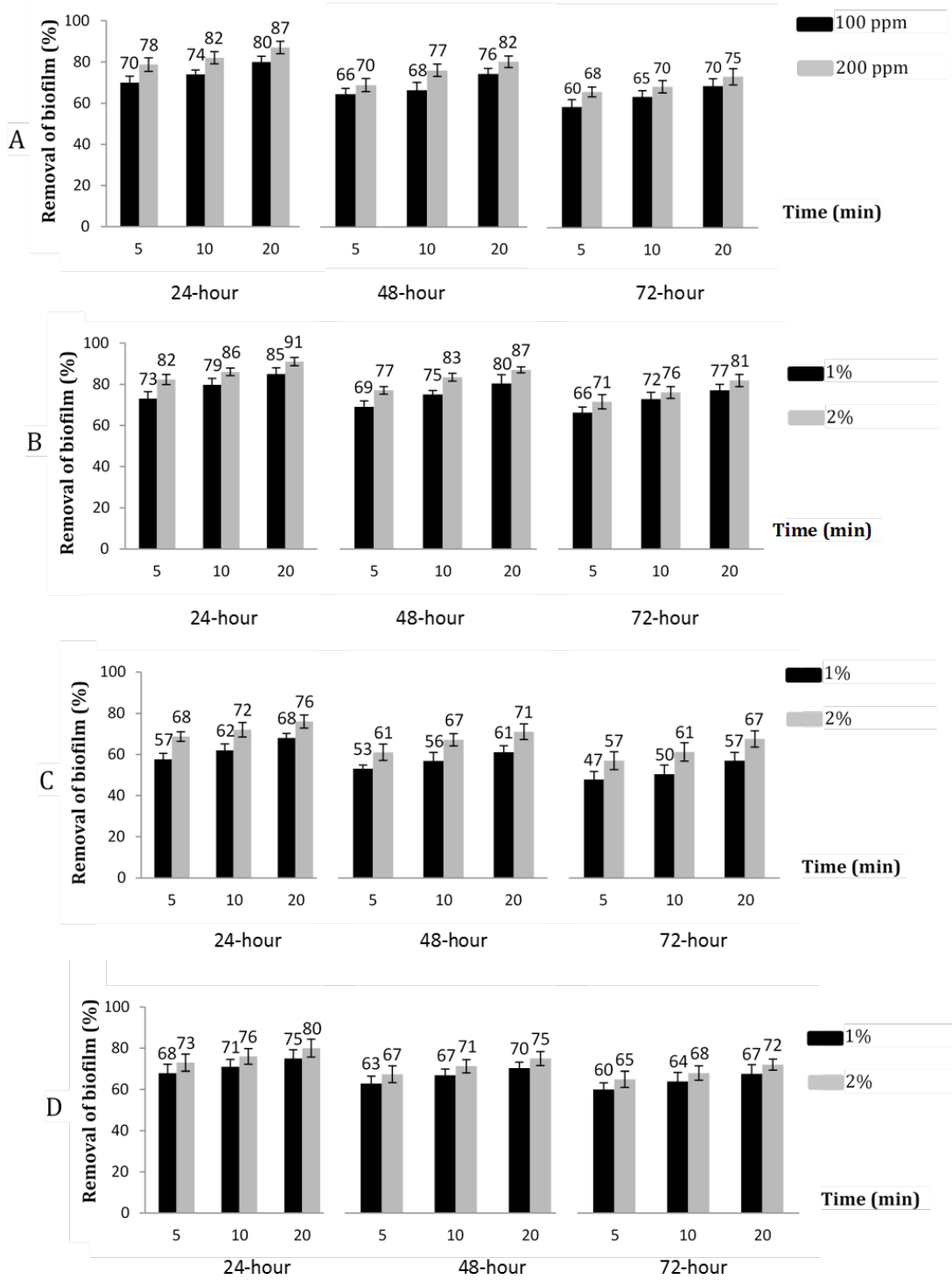

Figure 3. Effects of chlorine (A) and organic acid treatments (B: citric acid; C: malic acid; and D: gallic acid) for removal of 24 hour; 48 hour; and 72 hour E. coli biofilm formations on stainless steel coupons Mean values \pm standard deviation for three independent experiments performed in duplicate.

\section{Gallic Acid Treatments}

Biofilm formations were inhibited by $74-78 \%$ (p $<0.05)$ with $1 \%$ gallic acid treatments. However, substantially increased inhibitions were obtained by up to $78-81 \%(p<0.05)$ after $24-, 48-$ and $72-$ hour when the $2 \%$ of gallic acid was used before the biofilm formation (Figure 1D) .

Biofilm formations were decreased about 60$75 \%(p<0.05)$ by using $1 \%$ gallic acid for 5 to 20 min on 24-, 48- and 72-hour old biofilms. When the concentration of gallic acid was increased from $1 \%$ to $2 \%$, the removal ratios significantly increased to
$65-80 \%(p<0.05)$ after 5 to 20 min for $24-, 48$ - and 72-hour old biofilm formations (Figure 3D) .

\section{DISCUSSION}

The biofilm formation of microorganisms on food contact surfaces and processing facilities is a potential hazard for food processing industries [30]. Microorganisms can resist disinfection treatments when they form biofilms. Antimicrobial resistance becomes even worse when the microorganisms form biofilms [31]. Therefore, effective antimicrobial strategies are required. 
In this work, inhibition and removal of 24-hour, 48-hour and 72-hour biofilms of $E$. coli strain by organic acids compared to chlorine treatments were investigated on both microtitration plates and stainless steel coupons.

The reduction in pre-formed biofilm and the inhibition of biofilm formation by chlorine and organic acids were observed to be dependent on the dose and time (for removal) on both surfaces. The inhibition and removal of biofilm formation ratios were increased by increasing the concentrations of organic acid treatments from $1 \%$ to $2 \%(\mathrm{w} / \mathrm{v})$ or chlorine from $100 \mathrm{ppm}$ to $200 \mathrm{ppm}$ and the treatment times from $5 \mathrm{~min}$ to $20 \mathrm{~min}$ (for removal of biofilms). Even though the results indicated that $2 \%(w / v)$ organic acid treatments were more effective than $1 \%(w / v), 1 \%(w / v)$ concentration of organic acid treatments can be effectively used in practice to control biofilm formation.

A number of authors suggest that biofilm formed over an extensive period of time has increased resistance to antimicrobial substances [32,33]. Increased extra-polymeric substances and biofilm thickness over time are reported by some to enhance resistance to disinfectant agents [34]. It seems possible that hypochlorite may not have been able to penetrate effectively through the organic layers of the biofilm which may be the main reason for the loss of its effectiveness [35]. In the present work, biofilm formation of $E$. coli strain was developed in 24-hour and enhanced over 48-h with increased absorbance measurements. However, higher levels of biofilm formations were determined by using polystyrene microtitration plates than stainless steel coupons with lower absorbance values.

Bacterial adhesion to the surface depends on microbiological, physical, chemical, and materialrelated parameters. According to absorbance values, the attachment of $E$. coli strains was faster on microtitration plates than stainless steel coupons in the assays. The results agree with other studies $[36,37]$. It was determined that microorganisms attach more rapidly to hydrophobic surfaces such as polysytrene than to hydrophilic materials such as stainless surfaces. It was also indicated that the hydrophobicity of the cell surface was an important factor for the attachment of the bacteria to the surfaces [38-40]. This is due to the fact that hydrophobic interactions may lead to increase with an increasing nonpolar characteristics of surfaces involved [40]. Fimbriae or other proteins are needed for attachment on to hydrophobic surfaces [38]. Moreover, exopolysaccharides and lipopolysaccharides are important factors for attachment to hydrophilic surfaces [39]. Hyde et al. [41], found that biofilms consisting of E. coli grew better on polypropylene than stainless steel, while they did not grow well on glass. Therefore, it should be pointed out that hydrophilic materials should be used to render food contact surfaces like stainless steel, equipments and storage tanks.

Organic acids and chlorine were different in terms of their effectiveness for inhibition and removal of biofilm formations. This difference could be attributed to their mechanisms of antimicrobial action. Chlorine destroys microorganisms by chlorinating the lipid-protein substance in the bacterial cell wall to form toxic chloro compounds [42] and induces the leakage of macromolecules from the cells.

Organic acids were shown as inhibitors of many pathogenic bacteria $[16,17]$. The antimicrobial effect of organic acids could be related to several factors such as inhibiting metabolic acitivities or chain length [43]. It is also known that weak organic acids are lipophilic and penetrate plasma membrane acidifying the cell's interior. As bacteria maintain a neutral $\mathrm{pH}$ of the cytoplasm, the export of excess protons consumes cellular ATP and results in depletion of energy [44]. Various authors have hypothesized that organic acids may damage outer or cytoplasmic membrane, prevent synthesis of macromolecules and denature DNA reviewed by Ricke [44]. Ahn and Shin [45] reported that different types of organic acids exhibited different antimicrobial effects against different microorganisms.

Borges et al. [27] indicated that ferulic acid and gallic acids had effects in the prevention and control of biofilms of E. coli, L. monocytogenes, $P$. aeruginosa and $S$. aureus. Both phenolic acids had inhibition activity on biofilm formation and showed a higher potential to remove biofilm formations of the 
Gram-negative bacteria. The authors emphasized that gallic acid and ferulic acid reduced biofilm activity about $70 \%$ for all the biofilms tested.

In conclusion, citric acid treatments for inhibition of biofilm on microtitration plates were as effective as chlorine treatments. Gallic acid was found to be more effective inhibitor than malic acid. Moreover, citric acid treatments were as effective as chlorine treatments for biofilm removal on microtitration plates. Inhibitory efffects of sanitizers were higher than removal rates on microtitration plates. The results obtained from microtitration plates are found to be somewhat related to those determined from stainless steel coupons. On stainless steel surfaces, in most cases the inhibition and removal of biofilm rates were higher than those found on microtitration plates. Citric acid treatments were even more effective than chlorine treatments for both inhibition and removal of biofilms on stainless steel coupons. Gallic acid treatments were found to be more effective than malic acid treatments. The results of the study show that the effectiveness of organic acids for inhibition and removal of $E$. coli biofilms can be ordered in descending order as citric acid, gallic acid, and malic acid treatments on both surfaces.

It is important to achieve maximum control of biofilm formation with lower concentrations of sanitizers. The use of citric or gallic acids at concentrations of $1 \%$ or $2 \%(\mathrm{w} / \mathrm{v})$ can be considered as effective alternatives as commercial chemical sanitizers such as chlorine. Further studies are needed to determine the effects of these organic acids on different biofilm forming food related bacteria. Organic acid treatments to control E. coli biofilms are safe-to-use potential alternatives in industrial applications to chlorine treatments which are toxic to health and environment.

\section{ACKNOWLEDGEMENTS}

This work was supported by Gebze Technical University, Turkey under grant number 2014-A-08. Şeyda Çağ is acknowledged for technical asistance during laboratory work.

\section{CONFLICT OF INTEREST DISCLOSURE STATEMENT}

No potential conflict of interest was reported by the author(s).

\section{References}

1. P. Naves, G. del Prado, L. Huelves, M. Gracia, V. Ruiz, J. Blanco, G. Dahbi, M. Blanco, M.C. Ponte, F. Soriano, Correlation between virulence factors and in vitro biofilm formation by Escherichia coli strains, Microb. Pathog., 45 (2008) 86-91.

2. H.C. Flemming, Biofouling in water systems-cases, causes and counter measures, Appl. Microbiol. Biotechnol., 59 (2002) 629-640.

3. N. Oulahal, W. Brice, A. Martial, P. Degraeve, Quantitative analysis of survival of Staphylococcus aureus or Listeria innocua on two types of surfaces: Polypropylene and stainless steel in contact with three different dairy products, Food. Cont., 19 (2008) 178-185.

4. P. Cos, K. Tote, T. Horemans, L. Maes, Biofilms an extra hurdle for effective antimicrobial therapy, Curr. Pharm. Des., 16 (2010) 2279-2295.

5. M. Simoes, Antimicrobial strategies effective against infectious bacterial biofilms, Curr. Med. Chem., 18 (2011) 2129-2145.

6. V. Deibel, Biofilms, Int. J. Food. Safety, 1 (2003) 6-7.

7. R.H. Schmidt, D.J. Erickson, S. Sims, P. Wolff, Characteristics of food contact surface materials, Stainless steel. Food. Prot. Trends., 32 (2012) 574-584.

8. D.M.C. Pompermayer, C.C. Gaylarde, The influence of temperature on the adhesion of mixed cultures of Staphylococcus aureus and Escherichia coli to polypropylene, Food. Microbiol., 17 (2000) 361-365.

9. J.W. Austin, G. Berferin, Development of bacterial biofilms in dairy processing lines, J. Dairy. Res., 62 (1995) 509-519.

10. G. Mauriello, E. De Luca, A. La Storia, F. Villani, D. Ercolini, Antimicrobial activity of a nisin-activated plastic film for food packaging, Lett. Appl. Microbiol., 41 (2005) 464469.

11. D. Bermúdez-Aguirre, G.V Barbosa-Cánovas, Disinfection of selected vegetables under nonthermal treatments: chlorine, acid citric, ultraviolet light and ozone, Food. Cont., 29 (2012) 82-90.

12. K. Aarnisalo, J. Lunden, H. Korkeala, G. Wirtanen, Susceptibitity of Listeria monocytogenes strains to disinfectants and chlorinated alkaline cleaners at cold temperatures, Food. Sci. Technol., 40 (2007) 1041-1048.

13. J.R. Knowles, S. Roller, D.B. Murray, A.S. Naidu, Antimicrobial action of carvacrol at different stages of dual species biofilm development by Staphylococcus aureus and Salmonella enterica Typhimurium, Appl. Environ. Microbiol., 71 (2005) 797-803.

14. M.J. Saavedra, A. Borges, C. Dia, A. Aires, R.N. Bennett, E.S. Rosa, M. Simões Antimicrobial activity of phenolics and glucosinolate hydrolysis products and their synergy with streptomycin against pathogenic bacteria, Med. Chem., 6 (2010) 174-183.

15. F.M. Husain, I. Ahmad, M. Asıf, Q. Tahseen, Influence of clove oil on certain quarum sensing regulated functions and biofilm of Pseudomonas aeruginosa and Aeromonas hydrophila, J. Biosci., 38 (2013) 835-844.

16. S. Eswaranandam, N.S. Hettiarachchy, M.G. Johnson, Antimicrobial activity of citric, lactic, malic, or tartaric acids and nisin-incorporated soy protein film against Listeria monocytogenes, Escherichia coli, 0157:H7, and Salmonella gaminara, J. Food. Sci., 69 (2004) 79-84. 
17. M.Y. Akbas, H. Olmez, Inactivation of Escherichia coli and Listeria monocytogenes on iceberg lettuce by dip wash treatments with organic acids, Lett. Appl. Microbiol., 44 (2007) 619-624.

18. K.F. Over, N. Hettiarachchy, M.G. Johnson, B. Davis, Effects of organic acids and plant extracts on Escherichia coli 0157:H7 Listeria monocytogenes and Salmonella Typhimurium in broth culture model and chicken meat systems, J. Food. Sci., 74 (2009) 515-521.

19. USDA-FSIS, Safe and suitable ingredients used in the production of meat and poultry products, 2010, Directive 7120.1.rev.2.www.isis.usda.gov.OPPD E /dad/ FISIS directives/7120.1.Rev2.pdf Accessed January 11, (2011).

20. K. Nahar, S.M. Ullah, N. Islam, Osmotic adjustment and quality response of five tomato cultivars (Lycopersicon esculentumMill) following water deficit stress under subtropical climate, Asian J. Plant. Sci., 10 (2011) 153-157.

21. E. Shirzadeh, M. Kazemi, Effect of malic acid and calcium treatments on quality characteristics of apple fruits during storage. Am. J. Plant. Physiol., 6 (2011) 176182.

22. R.M. Raybaudi-Massilia, J. Mosqueda-Melgar, O. MartinBelloso, Antimicrobial activity of malic acid against Listeria monocytogenes, Salmonella Enteritidis and Escherichia coli 0157:H7 in apple, pear and melon juices, Food Cont., 20 (2009) 105-112.

23. L.R. Beuchat, D.A. Golden, Antimicrobials occurring naturally in foods, Food Technol., 43 (1989) 134-142.

24. R. Singla, H. Goel, A. Gangulli. Novel synergistic approach to exploit the bactericidal efficacy of commercial disinfectants on the biofilms of Salmonella enterica serovar Typhimurium, J. Biosci. Bioeng., 118 (2014) 34-40.

25. E. Obreque-Slier, A. Peña-Neira, R. López-Solís, F. Zamora-Marín, J. Ricardo da Silva, O.Laurean, Comparative study of the phenolic composition of seeds and skins from Carménère and Cabernet Sauvignon grape varieties (Vitis vinifera L.) during ripening, J Agri Food Chem., 58 (2010) 3591-3599.

26. A. Chanwitheesuk, A. Teerawutgulrag, J.D. Kilburn, N. Rakariyatham, Antimicrobial gallic acid from Caesalpinia mimosoides Lamk. Food Chem., 100 (2007) 1044-1048.

27. A. Borges, M.J. Saavedra, M. Simões, The activity of ferulic and gallic acids in biofilm prevention and control of pathogenic bacteria, Biofouling, 28 (2012) 755-767.

28. S. Stepanovic, D. Vukovic, I. Dakic, B. Savic, M. Svabic-Vlahovic, A modified microtiter-plate test for quantification of staphylococcal biofilm formation, J. Microbiol. Methods, 40 (2000) 175-179.

29. B. Pitts, M.A. Hamilton, N. Zelver, P.S. Stewart, A microtiter-plate screening method for biofilm disinfection and removal, J. Microbiol. Methods, 54 (2003) 269-276.

30. N.G. Chorianopoulos, D.S. Tsoukleris, E.Z. Panagou, P. Falaras, G.J.E. Nychas, Use of titanium dioxide (TiO2) photocatalysts as alternative means for Listeria monocytogenes biofilm disinfection in food processing, Food Microbiol., 28 (2011) 164-170.
31. T.F.C. Mah, GA. O'Toole, Mechanisms of biofilm reisitance to antimicrobila agents. Trends in Microbiol., 9 (2001) 34-39.

32. H. Anwar, JW. Costerton, Enhanced activity of combination of tobramycin and piperacillin for eradication of sessile biofilm cells of Pseudomonas aeruginosa. Antimicrob. Agents. Chemother., 34 (1990) 1666-1671.

33. A. Mangalappalli-Illathu, J. Lawrence, G. Swerhone, D. Korber, Architectural adaptation and protein expression patterns of Salmonella enterica serovar Enteritidis biofilms under laminar flow conditions, Int. J. Food Microbiol., 123 (2008) 109-120.

34. J.B. Xavier, C. Picioreanu, S.A. Rani, M.C.M. van Loosdrecht, P.S. Stewart, Biofilm-control strategies based on enzymic disruption of the extracellular polymeric substance matrix - a modelling study, Microbiology, 151 (2005) 3817-3832.

35. P.S. Stewart, J. Rayner, F. Roe, W.M. Rees, Biofilm penetration and disinfection efficacy of alkaline hypochlorite and chlorosulfamates, J. Appl. Microbiol., 91 (2001) 525-532.

36. M. Fletcher, GI. Loeb, Influence of substratum charactecristics on the attachment of a marine pseudomonad to solid surfaces. Appl. Environ. Microbiol., 37 (1979) 67-72.

37. S.C. Marques, J.G.O.S. Rezende, L.A.F. Alves, B.C. Silva, E. Alves, L.R. Abreu, R.H. Piccoli Formation of biofilms by Staphylococcus aureus on stainless steel and glass surfaces and its resistance to some selected chemical sanitizers, Braz. J. Microbiol., 38 (2007) 538-543.

38. Corpe WA. Microbial surface components involved in adsorption of microorganisms onto surfaces. In: Bitton G, Marshall KC, editors. Adsorption of microorganisms to surfaces. New York : John Wiley\& Sons; p. 105-144. domonad to solid surfaces. Appl. Environ. Microbiol., 37 (1980) 67-72.

39. V. Williams, M. Fletcher Pseudomonas fluorescens adhesion and transport through porous media are affected by lipopolysaccharide composition. Appl. Environ. Microbiol., 62 (1996) 100-104.

40. R.M. Donlan, JW. Costerton, Biofilms: survival mechanisms of clinically relevant microorganisms. Clinic. Microbiol. Rev., 15 (2002) 167-193.

41. F.W. Hyde, M. Alberg, K. Smith, Comparison of fluorinated polymers against stainless steel, glass, and polypropylene in microbial biofilm adherence and removal. J. Ind. Microbiol. Biotech., 19 (1997) 142-149.

42. C.N. Haas, RS. Engelbrecht, Physiological alterations of vegetative microorganisms resulting from chlorination, J. Water Pollut. Cont. Fed., 52 (1980) 1976-1989.

43. S. Doores, Organic Acids. In: Antimicrobials in Foods, Second Edition., (1993), Ch. 4, pp. 95-136. A. L. Branen and P. M. Davidson, eds. Marcel Dekker, Inc., New York.

44. Ricke SC. Perspectives on the use of organic acids and short chain fatty acids as antimicrobials. Poult. Sci., 82 (2003) 632-639.

45. Y.S. Ahn, DH. Shin, Antimicrobial effects of organic acid and ethanol on several foodborne microorganisms, Kor J. Food. Sci. Technol., 31 (1999) 1315-1323. 
